\title{
Correction to: Valuing genebanks
}

\author{
Melinda Smale $^{1}$ (D) $\cdot$ Nelissa Jamora $^{2}$
}

Published online: 26 January 2021

(C) The Author(s) 2021

\section{Correction to: Food Security (2020) 12(5):905-918 https://doi.org/10.1007/s12571-020-01034-x}

The article "Valuing genebanks", written by Melinda Smale and Nelissa Jamora, was originally published Online First without Open Access. After publication in volume 12, issue 5, page 905-918 the author decided to opt for Open Choice and to make the article an Open Access publication. Therefore, the copyright of the article has been changed to (C) The Authors 2021 and the article is forthwith distributed under the terms of the Creative Commons Attribution 4.0 International License, which permits use, sharing, adaptation, distribution and reproduction in any medium or format, as long as you give appropriate credit to the original author(s) and the source, provide a link to the Creative Commons licence, and indicate if changes were made. The images or other third party material in this article are included in the article's Creative Commons licence, unless indicated otherwise in a credit line to the material. If material is not included in the article's Creative Commons licence and your intended use is not permitted by statutory regulation or exceeds the permitted use, you will need to obtain permission directly from the copyright holder. To viewa copy of this licence, visit http:// www.creativecommonshorg/licenses/by/4.0/.

The original article has been corrected.

The online version of the original article can be found at https://oi.org/ 10.1007/s12571-020-01034-x

Melinda Smale

msmale@msu.edu

Nelissa Jamora

nelissa.jamora@croptrust.org

1 Michigan State University, East Lansing, VA, USA

2 Global Crop Diversity Trust (Crop Trust), Bonn, Germany
Also, the original version of this article unfortunately contained mistakes.

1. The number in page 2 should be changed from ' $95 \%$ ' to ' $23 \%$ '. Therefore, the sentence should be rewritten as:

While this represents only $10 \%$ of the total accessions stored in about 1750 genebanks around the world, the CGIAR genebanks account for about $23 \%$ of the germplasm distributed within the guidelines of the International Treaty on Plant Genetic Resources for Food and Agriculture (ITPGRFA) (ITPGRFA 2020).

2. There is an extra word "to" in page 9, section 3.6, that must be deleted. The original statement is "... secondary to use through sharing...". It should be "... secondary use through sharing...". Therefore, the sentence should be rewritten as:

For example, the US NPGS survey indicated higher rates of direct utilization in plant breeding than had been suggested in earlier studies, secondary use through sharing within and outside respondents' institutions, and proportionately higher use rates among respondents in low- and middleincome countries (Smale and Day-Rubenstein 2002).

Open Access This article is licensed under a Creative Commons Attribution 4.0 International License, which permits use, sharing, adaptation, distribution and reproduction in any medium or format, as long as you give appropriate credit to the original author(s) and the source, provide a link to the Creative Commons licence, and indicate if changes were made. The images or other third party material in this article are included in the article's Creative Commons licence, unless indicated otherwise in a credit line to the material. If material is not included in the article's Creative Commons licence and your intended use is not permitted by statutory regulation or exceeds the permitted use, you will need to obtain permission directly from the copyright holder. To view a copy of this licence, visit http://creativecommons.org/licenses/by/4.0/. 